\title{
Instructional Strategies for Motivating and Engraining Generation Z Students in Their Own Learning Process
}

\author{
Mohammad Afshin Afshar \\ Payame Noor University (PNU), Tehran, Iran \\ E-mail: afshinafshar@live.com
}

Alireza Jafari

Inflammatory Lung Disease Research Center, Guilan University of Medical Sciences, Rasht, Iran. dr.alireza.jafariii@gmail.com

Fariba Heshmati

Iran University of Medical Sciences, Tehran, Iran Heshmatifariba1339@gmail.com

Farahnaz Movahedzadeh Department of Biological Sciences, Harold Washington College, USA. fmovahedzadeh@ccc.edu

\author{
Abour H. Cherif \\ American Association of University Administrators (AAUA), USA \\ acherif@aaua.org
}

\begin{abstract}
In the last few years, a number of significant research studies were conducted focusing on identifying and determining the root cause and also factors that critically contribute to students failure and success in higher education. These studies have enabled educators to evaluate the underlying causes by analyzing different perspectives presented by students, faculty and academic leaders. Various studies were conducted and published in the past that have addressed the same issue. For example, in three related studies conducted and presented at the Higher Learning Commission (HLC) conference in Chicago, Illinois, the surveyed participants (students, faculty, and academic leaders) provided concrete root-cause factors for student's failure at college and university level. Student's academic readiness, self-motivation, study habits, and students attitude towards education were the most mentioned root-causes by both, faculty and academic leaders (Appendix 1). During the studies, all participants agreed upon the fact that in order to succeed, students should have clear mindsets and should be aware of the reasons and requirements they will need to meet in order to enroll in a specific course. They should be thoroughly aware of their purpose for attending a school beyond just getting passing grades and a degree to get jobs. However, all three surveyed groups strongly believe that it is not only the student's responsibility, but also the responsibility of instructors and college administration to keep students motivated after admitting them to their colleges, programs, and courses (Cherif, Movahedzadeh, Adams, Martyn 2013; 2014; 2015). In this paper, we explore the implementation of some proposed recommendations from various research studies for improving students learning and instructors teaching in a classroom setting.
\end{abstract}

Keywords: Modern students, Motivations; Student academic performance and retention, Student success.

DOI: $10.7176 / \mathrm{JEP} / 10-3-01$

\section{Introduction: Modern Students and Today's Learners}

There is no doubt in the fact that the way we teach and engage students in learning has a profound effect on student's attitude and performance in college-level courses and in turn affecting their ability to complete and succeed in respective courses. Unlike all the previous generations, today's students are being raised in an age of rapidly advancing technology. They are exposed to digital media and have easy access to free information 24/7. This makes them different from earlier generations of learners when digital technology was not as widespread as it is nowadays. They have become more tech-savvy than ever before, and most have grown up using computers and the Internet since, and for some even before, first grade. They are native digital users, more digitally connected and most of them make the Internet and digital information as their main educational preference and way to learn, communicate and socialize with others. 
A recent report prepared and published by Chronicle of Higher Education (CHE 2018), shows that today's new generation of students which are called Generation Z (Gen Z) is "more skeptical and money conscious, interested in an education they can apply and focused on the value of a degree. Technology is indispensable to them but not always a net positive, and they may need more in the way of personal development than their predecessors did." (CHE, 2018). To help this generation of students to learn and be successful in school we, the educators, first need to know their style of learning and then we need to continuously adapt and re-design our college learning resources and environment that resonates with Gen $\mathrm{Z}$ and every other tech-savvy that comes after them. But who are the modern learners who are called Generation Z? As seen in Table 1, explained by Dillon Kalkhurst (2018), a preeminent authority on multigenerational engagement research:

Generation $Z$ is the youngest of the five generations, active in today's economy. They are already the largest generation in the U.S. and will represent 40 percent of the population in 2020. In the world of higher-education, Gen $Z$ accounts for all of the students enrolling today. Generation $Z$ has experienced the most change in their short time on earth. Most of those changes center around technology. Gen $Z$ is disrupting decades-long practices in our education system, forcing colleges and universities to adapt at a rapid pace or become irrelevant." (Kalkhurst, 2018, ף.1).

For example,

While Millennials used three screens on average, Gen $Z$ students frequently use up to five. Most use a smartphone, TV, laptop, desktop, and a tablet. These devices occupy ten hours of Gen Z's daily activity. The constant stimulation and access to all the world's information at their fingertips has given them an eight-second attention span and has trained their brains to expect instant gratification. Sitting in a hall or classroom listening to a lecture is Gen Z torture. Gen Z students want a chance to be part of the learning process, not a passive bystander. (Kalkhurst, 2018, ๆ.3).

In the previous study, students, faculty, and college administrators indicated that most of today's students lack motivation and not sufficiently prepared for college academic work (Appendix 1), therefore, how can we teach modern students to motivate them to spend their time, energy, and efforts on learning? We know that when students are actively engaged and see values and relevancy in what they learn, they become naturally motivated; meaning basically willing to spend extra time, energy, and efforts in their own learning and education.

Table 1: The Five Distinct Identified Generations

\begin{tabular}{|l|l|l|}
\hline \multicolumn{3}{|c|}{ Many of Today's Workplaces Are Composed of Five Distinct Generations } \\
\hline \multicolumn{1}{|c|}{ Generation Name } & \multicolumn{1}{|c|}{ Born } & \multicolumn{1}{c|}{ Example of Main Traits \& Characteristics } \\
\hline $\begin{array}{l}\text { Generation Z, iGen, or } \\
\text { Centennials }\end{array}$ & After 1997 & $\begin{array}{l}\text { Entrepreneurial and tech-savvy, have different media consumption } \\
\text { habits from all previous generations, value and prefer cool products } \\
\text { over cool experiences, often respond positively to edgy campaigns, } \\
\text { have need and desire to co-create culture in which they live, want to } \\
\text { earn their own income. More than 60\% of them (2.52 billions) want to } \\
\text { change the world. On the average they use their smartphones 15.4 } \\
\text { hour) per week and watch less TV content per week (13.2 hours) than } \\
\text { baby boomers (24.1 hours) and Gen X (19.7 hours) (Novak, 2018; } \\
\text { Kleinschmit, 2018). }\end{array}$ \\
\hline $\begin{array}{l}\text { Generation Y, or } \\
\text { Millennials }\end{array}$ & $\begin{array}{l}\text { Between } \\
1977 \& 1997\end{array}$ & $\begin{array}{l}\text { Time efficient, schedule everything, respect authority, optimistic, } \\
\text { focused (Novak, 2018). }\end{array}$ \\
\hline Generation X & $\begin{array}{l}\text { Between } \\
\text { Baby Boomers }\end{array}$ & $\begin{array}{l}\text { Independent and highly individualistic, resourceful, and self-sufficient. } \\
\text { They value freedom and responsibility in the workplace. Values work } \\
\text { and life balance, technologically adapt, flexible (Kane, 2018). }\end{array}$ \\
\hline $\begin{array}{l}\text { Traditionalists or Silent } \\
\text { Generation }\end{array}$ & $\begin{array}{l}\text { Strong work ethic, independent and self-assured, competitive and goal- } \\
\text { centric, resourceful, and mentally focused, disciplined and team } \\
\text { oriented, to name a few (Pappas, 2016). }\end{array}$ \\
\hline $1946 \& 1964$ & $\begin{array}{l}\text { They are conservative with strong traditional family values; Strive for } \\
\text { comfort, and financial security; Demand quality but simplicity; } \\
\text { Patriotic, Patience, Team player and understands the nobility of sacrifice } \\
\text { for the common good; Loyal to employers and expect the same in } \\
\text { return; Possess superb interpersonal skills, work hard, and have high } \\
\text { work ethics; Hold the attitude of "Waste not want not" and children } \\
\text { were "seen, but not heard", to name a few (Howe, 2014). }\end{array}$ \\
\hline
\end{tabular}


Motivating students is an important issue in higher education, so how can we assist faculty and in turn colleges and universities to predict students' academic performance and identifying the students before their grades begin to fall (Kamauru, 2000). It has been widely reported that the passion to learn among students seems to shrink as children grow (Lumsden, 1994). This is simply because learning sometimes becomes compulsive than pleasure. Indeed, "there is a growing argument that the most powerful, relevant learning for today's students is happening when they connect with the rapidly changing world beyond the school walls (Bushweller, 2019, ๆ.5), that might be one of the reasons why a large number of students drop out of school before graduation. Due to the unpleasant attitude of students toward education, so often, only very few are actually mentally present in the classroom.

As shown by Dr. Movahedzadeh (2015) and her research team, the good news about motivation is that because of human nature, every student is motivated by something and every student can be motivated. The challenges for faculty and educators are finding what motivates each student and finding how to motivate each student for the specific topic, course, and academic program (figure 2). If students can learn when they are engaged, then how can we secure such an engagement? After all, as Sackstein, (2019) convincingly argued, as educators "we have an obligation to bring wonder and curiosity to our classrooms to engage students with the everyday magic of learning and how our imaginations are the only thing that can possibly limit us in this world” (ף. 5).

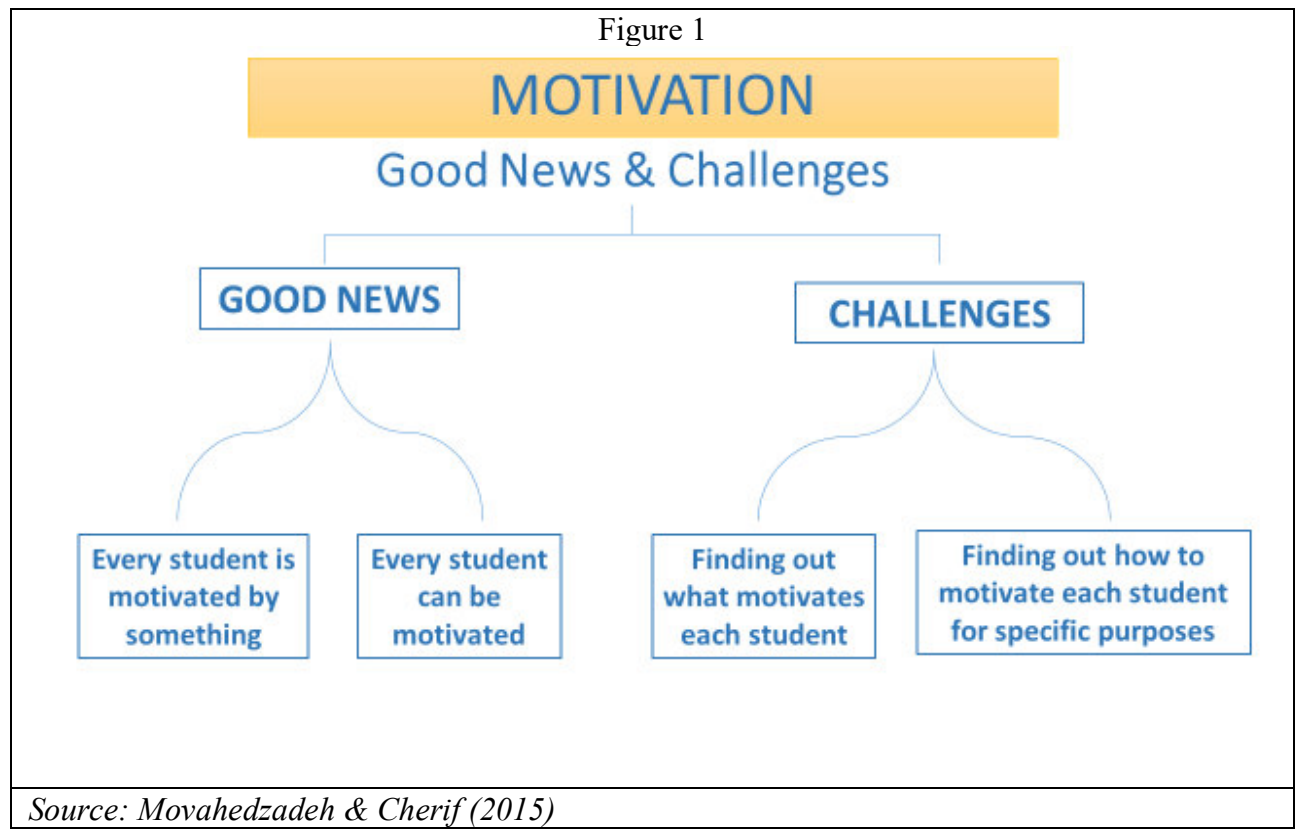

Since motivation is a self-inner drive to do a specific action or behavior (Ryan \& Deci, 2000; Fowler, 2014), student's self-interest and motivation is the element that leads students' attitude towards the learning process. Numerous studies have been conducted to probe the role of student motivation toward academic performance and different definitions of students' motivation have been used by various researches. For instance, Lumsden (1994), analyzed students' involvement towards education and the sources of their motivation. Marshal (1987) viewed students' motivation as a critical force beneficial to the learners. Ames (1990) stated that the motivation to learn is dependent on long-term, quality attachment in learning and pledge to the process of learning. Most motivation theorists believe that motivation is involved in the performance of all learned responses and learned behavior will not occur unless it is energized by self-motivation. Bomia (1997) has suggested student motivation as student willingness, need, desire and obligation to participate and be booming in the learning process. Finally, as Robyn R. Jackson (2011) explained in her book "How to Motivate Reluctant Learners", "What we call motivation in school is really a decision students make to invest in our classrooms. It's our responsibility to show students the value of investment and guide them toward behaviors that will support learning” ( 1 . 1). What Jackson is really calling for is "to create a classroom learning environment, and learning strategies in which students will invest by removing demotivating practice- and procedure-based barriers and giving students more opportunities for autonomy on how to learn and communicate what they learn to others "(ף. 4).

Educational psychologists and motivational theorists often separated students' motivation into two distinctive 
categories: Intrinsic Motivation and Extrinsic Motivation (e.g., Ryan, \& Deci, 2000; Jackson, 2011; Fowler, 2014). A student is intrinsically motivated when he or she is motivated from within. Intrinsically motivated students keenly engage themselves in learning out of oddity, interest, or enjoyment, or in order to achieve their own scholarly and personal self-goals. Thus, students with intrinsic motivation are more enthusiastic, self-driven, challenging, have high self-efficacy, and feel pleasure in their studies. On the other hand, extrinsic motivation is a reward-driven behavior controlled by external factors such as rewards, incentives, praise, fame, money, grades, etc. As a result of this, students with extrinsic motivation often try to drag themselves with academic assignments, feel compelled to learn, and always put minimal effort to achieve maximum appreciations. Unlike intrinsically motivated students who tend to enjoy learning and utilize strategies that require more effort and that allow them to process information more intensely, extrinsically motivated students are expected to be rewarded for their efforts and so often they wait until they are sure they are going to be rewarded. With this in mind, it is safe to argue that faculty who use instructional methods and strategies that provide the opportunities for students to be engaged in both the teaching and the learning process would have more motivated students who are intrinsically willing to spend more time, energy, and efforts in their own learning process. After all, as Dr. W. Edwards Deming, a pioneer of quality management, clearly explained, we, as human beings, "are born with intrinsic motivation, self-esteem, dignity, curiosity to learn, joy in learning” (cited in Markova, 1992, p. i). Indeed, as anthropologist Edward T. Hall pointed out, implanted in our own innate nature the drive to learn is more basic than the drive to reproduce (cited in Markova, 1992, p. ii). So as educators we need to learn how to get to know our students, and then learn how to move those extrinsically motivated students, away from dependence on external rewards. Then help them to discover how their jobs as students and learners can meet the deeper psychological needs (for autonomy, relatedness, and competence) that result in meaningful and sustainable motivation that is required for success in school work as well as in their lives (Fowler, 2014).

\section{Are Modern Students Aware Of What Makes Them Effective Learners?}

The answer to this question is most likely yes. First of all, today's students have been raised in an age when technology is advancing rapidly. They're constantly exposed to digital media and access to free information, making them very different from earlier generations of learners when digital technology was less developed. They are more tech savvy than ever before, and most have grown up having internet access all the time. They are native digital users, making the Internet and digital information their main educational preference, gateway, and ways to learn and communicate with others within and outside their own families and communities. Furthermore, today's learners are more visual and kinesthetic than any generation before; comfortable in disengaging from something they don't find interesting or relevant; prefer to work on things that matter so they can make a difference. Today's learners are also very busy, and their learning is constrained by a lack of time. Students use email $90 \%$ of the time to communicate with professors and $73 \%$ of the time they claim they cannot study without technology. They develop a dependency on technology. Merely more than 35\% of today's students can't go more than ten minutes without checking their smartphones or other devices. In addition, more than $2 / 3$ of college students are using YouTube videos as a source of learning about academic topics and concepts without even being told to do so by their own professors (Cherif, Siuda, Movahedzadeh, Ayesh, Martin, and Cannon, 2014). What is clear is that many faculty, instructors, and administrators are still teaching today's students the way they were taught and not the way they wanted to be taught. Furthermore, many instructors forget the importance of the first day of the class meeting and how this can leave a long-lasting impression on students that could affect students' motivation and performance not only during their college life but also could shape their careers and future Indeed, the first day of class is crucial not only for the students, but also for the faculty and instructors. Failure to make the opening day as effective as possible in motivating and inspiring the students about both the content of the course and the class, could lead to lower student success rate at the end of the semester (Metzger 2013; Lang, 2019). The conclusion is that as Price (2013), a psychologist at Dalton State College, described that while "Modern learners have a different mind-set about education, this doesn't mean they don't want to learn. They just go about it differently". Today's students know how they can be motivated to be actively engaged in the learning process. For example, in previous studies and as shown in Figure 1, students specifically indicated that they want faculty and instructors to communicate with them by the language they understand, tools they can use, and technology which they are familiar with. They also indicated to be engaged in both, the teaching and learning processes, to be given responsibilities that lead to accountabilities and to help them develop higher expectations \& then demand higher expectation from them in return (Cherif, Movahedzadeh, Adams, Martyn 2013).

Figure 2 


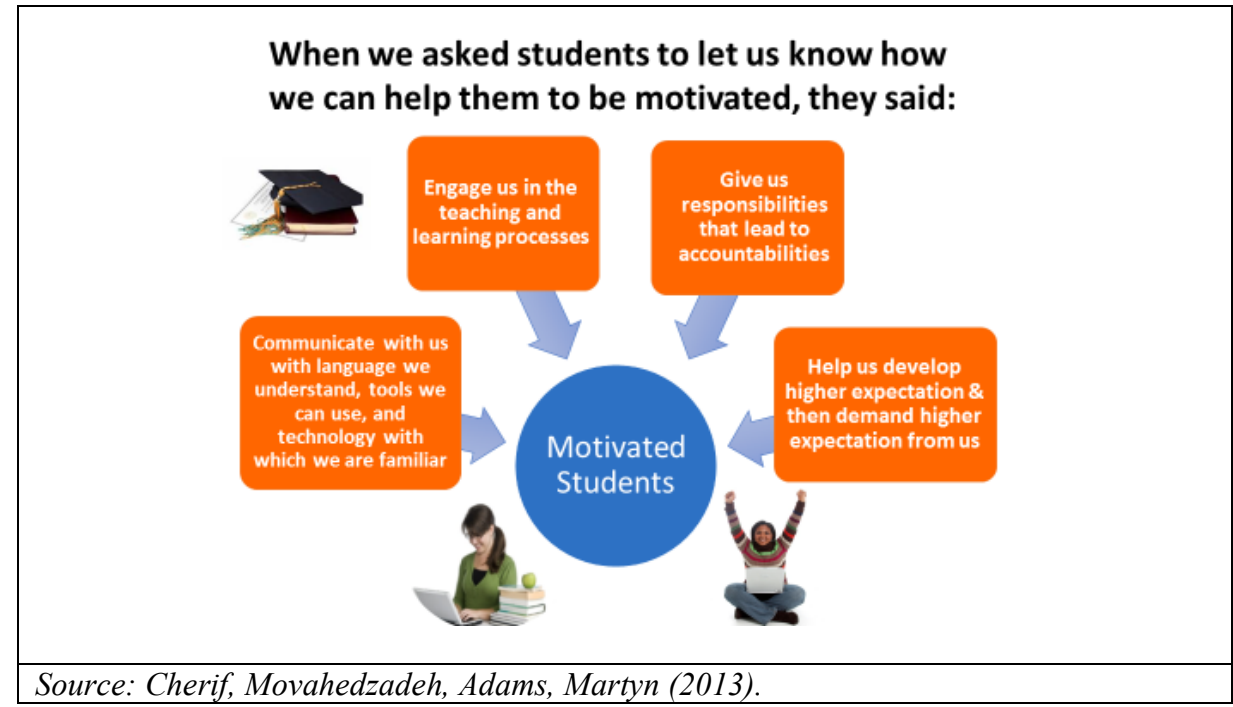

On the other hand, in one of the studies the surveyed faculty were asked to identify the most critical challenges facing their college students in learning from their own perspectives, the faculty in one study (Cherif, Movahedzadeh, Adams, Martyn, 2014), stated that they would like their students to:

- Have the needed academic background for their chosen academic careers.

- Believe they can do it! Anything is possible through determination and hard work.

- Be willing to ask questions and accept the fact that they are here to learn and asking questions is part of the learning process.

- Build the bridge between what they know, what they learn, and real-life!

- Find out their own best ways to study and to learn!

- Learn how to best manage time and life priorities!

\section{Inspiring, Motivating and Supporting Student's Learning}

In searching for instructional strategies and teaching approaches that help in inspiring, motivating, and support students in their learning, we need to attest that we do agree with both Robyn Jackson (2011) and Christy Price (2013) in stating that "Modern learners have a different mind-set about education, this doesn't mean they don't want to learn. They just go about it differently". In addition, "What we call motivation in school is really a decision students make to invest more of their time and energy in our classrooms. In this sense, it's our responsibility to show students the value of investment in our courses and guide them toward behaviors that will support learning." These two realizations are essential in searching for instructional strategies and teaching approaches that help in inspiring, motivating, and support students in their learning, Therefore, it is the responsibility of faculty, instructors, and college administrators to show students the value of investment in college courses and academic programs and to guide them toward behaviors that will not only support but also maximize learning. After all, motivation is a state of mind, an inner force of persistence that energize, direct, and sustain desirable behavior (Palmero 2008; Ryan \& Deci, 2000; Fowler, 2014). It involves "goals and requires activity. Goals provide the impetus for and the direction of action. While action entails effort, persistence in order to sustain activity for a long period of time". Active learning requires transforming the course, the class and the classroom into a Center for Active Learning.

\section{Selected Examples of Strategies and Techniques For Motivating and Inspiring Students:}

We teach so students can learn, and to learn is to acquire understanding of something that one doesn't have before (Barrow and Milburn, 1990). And since communication is at the heart of what it means to be human being and to connect with others and the world around us, then learning is also about making connections and using the acquired new knowledge and information to solve problems that arise in a context different from which the information was originally taught (Cross, 1999). With this in mind, the following are a few examples that we have found to be very useful in helping students to be motivated and invest more of their own time and energy in their own learning processes. We need to re-structure our courses and the strategies in the way we manage and deliver them. We also need to teach the students as they are and not as we wish they were. After all, the purpose 
of Higher Education is "to help college students become 'Intentional Learners' who can adapt to new environments, integrate knowledge from different sources, and continue learning throughout their lives" (Greater Expectations, 2002 AACU Report). But most of all it is not about the content, per se, but it is about helping students to connect with the learning in a way that is exciting, inspiring, and joyful throughout one's life (Sackstein, 2019).

\subsection{Free-classroom Creative Assignment}

Knowing our students beyond the classroom is key in motivating students by capitalizing on understanding what they can do best resulting in success in the course. The more we know about our students, the better we are as instructors and educators. Furthermore, one common thing among effective instructors is that they all provide their students with the opportunity to have autonomy in the learning process. Students would make the learning materials and the learning experience become relevant not only to student's daily life, but also to the environment, and their community (Cherif, 2011). Even though talents vary between students, every individual naturally has certain abilities, skills, capabilities, or aptitudes, as well as physiological needs for motivation which include autonomy, relatedness, and competence (Fowler, 2014). For students, such talents and needs can be discovered, evoked, and enhanced if the right environment is provided, one that offers the means and the freedom to explore and express what they learn in media of their own choosing (Cherif, Roze, and Gialamas, 2016).

One way to better understand our students is to give them an assignment after the first week of the class and give them the freedom to demonstrate their understanding of the learned concept in a medium of their own choice. The goal of the assignment is to give the instructor the opportunity to know what every individual student is good at such as in writing, in a drawing, in graphic design, computer design, music, cartoons, storytelling, etc. This information is important for when faculty design or re-design their learning assignments, homework, lesson plans, etc. This, most of all gives students the indication that their instructors know them very well, care about them, and care about their education wellbeing. In short, Free-Classroom Creative Assignment explores the importance for teachers, of knowing and taking advantage of students' skills, abilities, aspirations, and talents. Leveraging such insights can help redesign teaching to advance students much more efficiently and creatively (Cherif, 2011; Lang, 2019).

\subsection{A Challenging Problem at the Beginning of Each Class Meeting}

Learning is about making a connection between what we know and what we want to know and learn and how to communicate all these to others and the world around us. It "requires a challenge that opens the door for the learner to actively engage his/her peers, and to process and synthesize information rather than simply memorize and regurgitate it" (Smith and MacGregor, 1992; Lang, 2019). Start every class by introducing a problem that needs to be solved and challenging the students on how this problem could be dealt with and solved. Give students enough time to think, converse with their fellow classmates, and then have an open class discussion about some of the proposed causes and solutions. Use this as a passageway to the class's intended learning objectives including materials, concepts, and labs. Educators need to create a learning environment that allows for more inclusive classroom meaningful discussion that leads to the development of authentic collaboration and self-reflective communication among the students.

\subsection{Project-based-Learning}

About fifteen years ago, the National Research Council (NRC 2003) suggested that opportunities for gaining a greater understanding of science could be realized through project-based laboratory courses (Treacy, 2011). Project-Based Learning (PBL) is a method in which students engage in intellectually challenging tasks that drive inquiry questions through gaining content knowledge and academic skills to solve complex problems and informatively defend their solutions and outcomes. This method "allows students to work actively with the applied techniques of the laboratory setting while incorporating critical thinking, collaboration, and problemsolving skills in the context of content-based knowledge that influences comprehension and academic selfconfidence" (Movahedzadeh, et. al, 2012, p. 1). Among the keys to successful project-based learning are challenging students to tackle large but specific topics, while setting milestones and schedules to keep them organized, and to productively progress forward along the class learning materials and objectives (Movahedzadeh, et. al, 2012; Berchiolli and Movahedzadeh, 2018; Schuetz, 2018). 


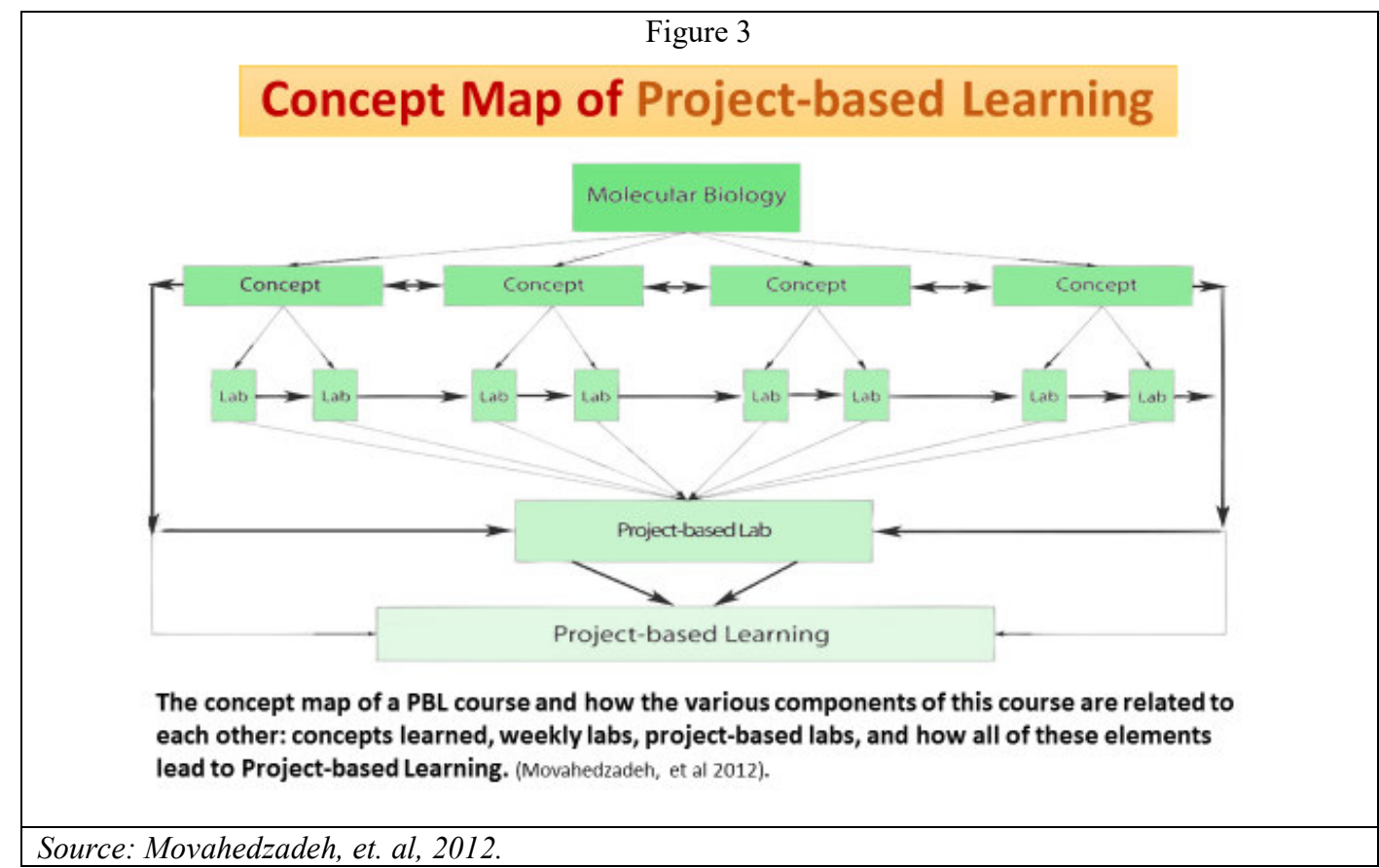

As seen in the figures above and below, Project-Based-Learning can involve a specific course targeting a specific problem, issue, and/or matter. Also, it can be part of a college project that involves several courses from different academic disciplines that focus on the same problem, but each approaching from its own nature and perspectives. This means students in each course investigate the problem from their own course content. In the end, students involve different courses, collectively contribute to the investigation and the potential solution of the presented problem (Figure 3 and 4). For example, In the Biology Department at Harold Washington College of Chicago, students investigated bacteria in the Chicago River (Movahedzadeh, et. al, 2012), in another class, students investigated and identified the bacteria that exists in elevators and escalators within the campus (unpublished data). Most of the students who took for example, these two classes reported at the end of the semester that they had very rewarding and unforgettable learning experience.

While the challenge, question, or the problem students are assigned to work on through PBL classes are different from class to class or school to school, for practical reasons and simplicity. Robert Schuetz, (2018) identified seven essential elements that each project-based learning should have to ensure a level of success. They are as follows:

- Focuses the student on a big open-ended question, challenge, or problem to research and respond to and/or solve.

- Brings what students should academically know, understand, and be able to do into the equation.

- Is inquiry-based.

- Uses 21st-century skills such as critical thinking, communication, collaboration, and creativity, among others.

- Builds student choice into the process.

- Provides opportunities for feedback and revision of the plan and the project.

- Requires students to present their problems, research process, methods, and results.

(Schuetz, 2018, ๆ. 8) 


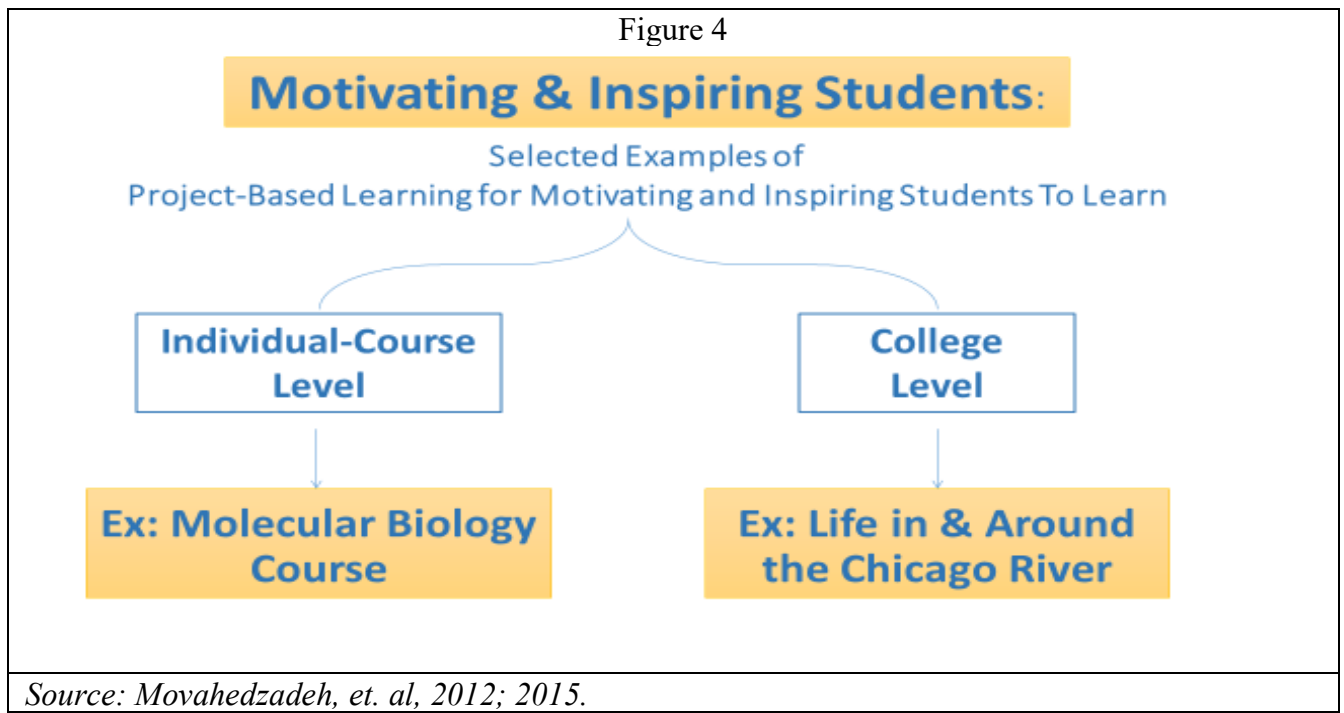

In summary, in Project-based learning students work in groups to conduct and complete a project as a means of mastering educational concepts and objectives through investigating solutions to a complex, semester-long identified challenge. Through the process the students act as investigators, doers, and movers while teachers, faculty, and instructors act as professional consulting partners and academic experts (Figure 5).

Figure 5

\section{Role and Responsibilities In PBL}

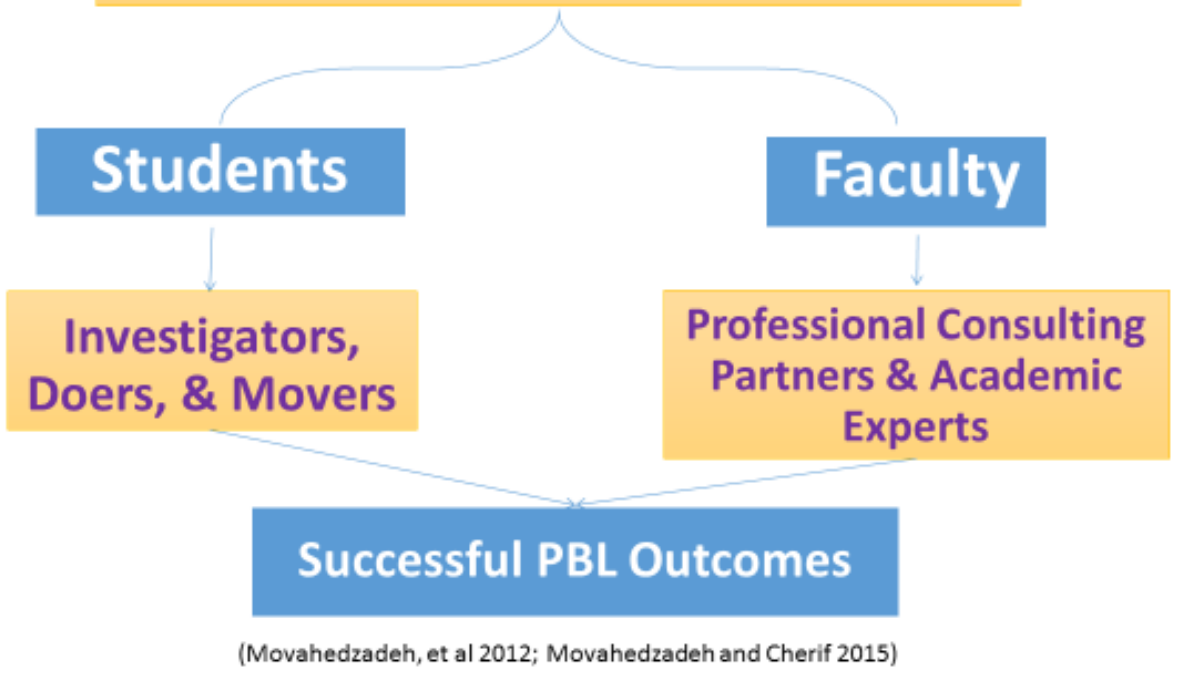

\subsection{Flipped Learning Model}

The Flip approach reverses the traditional way classes are designed, taught, and assessed. Simply stated, the Flipped Learning model requires faculty and students to reverse what happens "in" and "out" of the classroom. All the needed material that might have been delivered in lecture format is provided in advance to the students via reading or pre-recorded lecture videos and related web-tools. Class time is replaced with group work, discussion, labs, problem-solving and other forms of highly engaged participatory learning, which become "the norm."

In addition, students would reverse their schedule. What they would do outside the class time such as homework 
and whatever happens during a typical class such as lectures would be switched. This could include watching videos of lectures, critically review and analyzing recent related literature, or conducting research for homework "out of class" and then come to class to engage in problem-solving, and in-depth discussion, lab investigation and related activities.

In higher education, Flipped Learning is viewed as but not limited to:

- A learner-centered approach

- Uses web-driven technology

- A blended learning teaching approach

- Exposes students to pre-recorded course content through instructional short videos, podcasts, or other means to be prepared for active class meetings.

- Actively engages students with the same materials in and during class time by interacting with peers and faculty in synchronous discussion activities.

- Interactive during face-to-face sessions.

A typical homework assignment for students in the Flip model is to watch the lectures or pre-recorded videos by the instructors before they come to class. With this preparation, the instructors can use the class time to give more examples, discuss specific issues in detail, work with groups, investigate problems and work with students individually. Outside the class, students focus on gathering information, memorizing, understanding, and applying. Inside the class, students focus on analyzing, evaluating what they read and create new knowledge and applications. As seen in Figure 6 below, students can spend more time analyzing, evaluating, and creating new knowledge, understanding, and application of what they already learned. In doing so, they are more engaging in and spending more time on learning through Bloom's higher learning objectives than lower learning objectives.

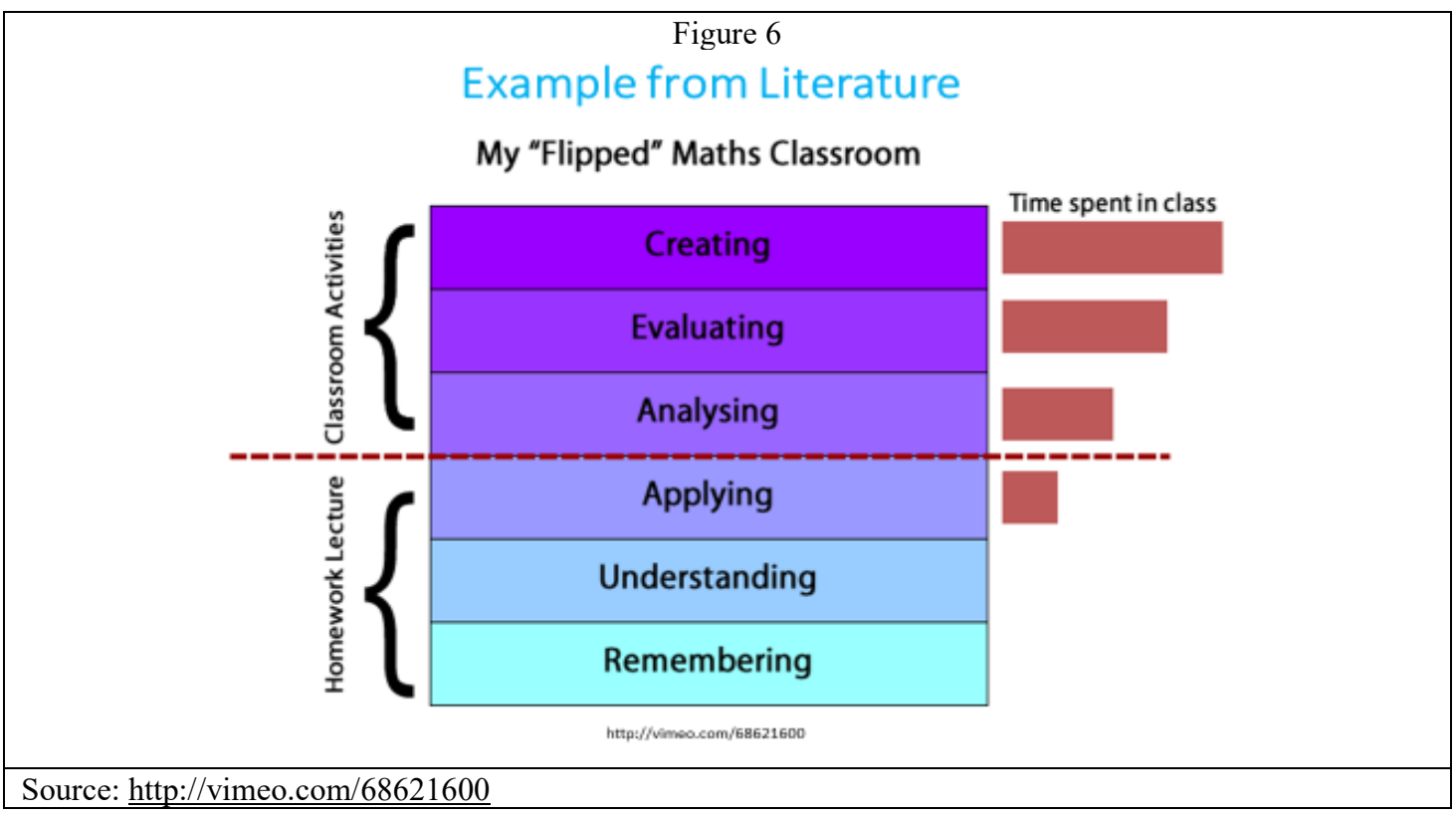

However, as Honeycutt and Glova, 2014 argues,

At its core, the flip means shifting the focus from the instructor to the students. You can do this by inverting the design of the course so students engage in activities, apply concepts, and focus on higherlevel learning outcomes (Honeycutt \& Garrett, 2013). Using this definition, the flip moves away from being defined as only something that happens in class vs. out of class. Instead, we focus on what are students doing to construct knowledge, connect with others, and engage in higher levels of critical thinking and analysis. This applies to both the online and face-to-face environment. The real flip is not about where activities take place-it's about flipping the focus from you to your students.

(Honeycutt and Glova, 2014, h. 9)

For example, in a study titled "Do College Students Give Flip About Flip Learning”, the majority of the participants who participated in this study perceived "Flip Learning" model as particularly helpful for learning 
the subject matter, assessing what they know, gaining important learning skills and improving their personal methods of learning. Furthermore, the study shows regardless of whether or not the students experience the Flip learning, the model appeals to them and they were willing to give it a try in their math, science, and business classes (Cherif, Adams, Movahedzadeh, Martyn, McManamon, 2015).

\subsection{Blended Learning}

Hybrid or Blended Learning is an approach that combines the use of digital learning tools with face-to-face teaching. It combines the best of online learning and the best of onsite learning to promote and support personalized learning and success (Figure 7). Specifically, in blended courses, a portion of the traditional faceto-face instruction is replaced by web-based online learning that students must complete on their own before they come to a face-to-face class meeting. While much of the face-to-face instruction must be replaced by online work, it depends on the type of class, discipline, as well as the learning objectives. The Online Learning Consortium defines blended learning as a course where $30-70 \%$ of the instruction is received online. In the blended system, face-to-face and online modes of learning are combined in order to enhance the learning and teaching experience for both students and faculty. Using computer-based technologies and web-based course delivery, instructors use the hybrid model to redesign some lectures or lab contents into new online learning activities such as case studies, tutorials, self-testing exercises, simulations, online group collaborations, and threaded discussions. Blended learning systematically incorporates the use of asynchronous teaching (facilitated by computer-based technologies) into the traditional onsite teaching in order to maximize both teaching and learning opportunities (e.g., Garrison and Vaughan, 2008; Movahedzadeh, et. al, 2012; Cherif, et, al. 2013).

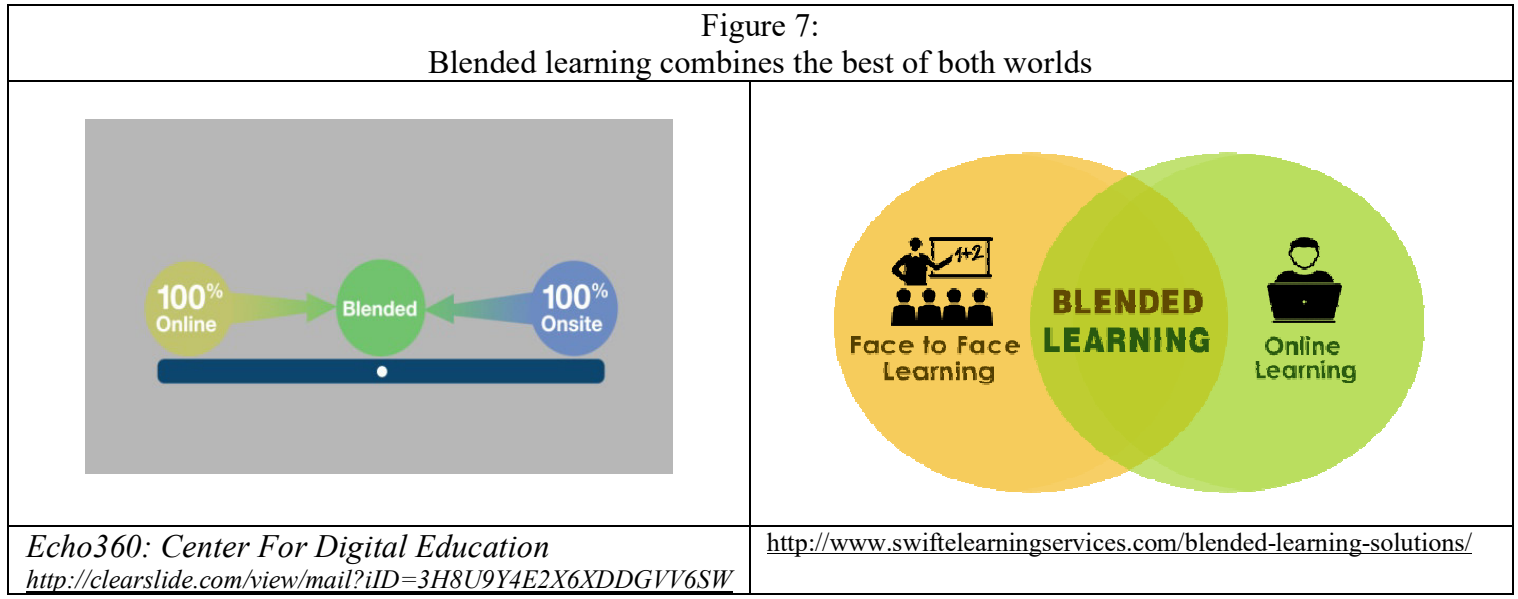

Finally, a few researchers have been arguing that blended learning helps instructors to meet and cover all learning styles whether they learn best in the classroom or best on the computer. What is sure is that effective blended learning uses the best of both words solutions that "can help you cater for all learning styles since you have access to so many learning mediums and techniques" (Spencer, 2016, ๆ.8).

\subsection{Collaborative Learning}

There is accumulated evidence that people generally learn best in an environment of collaboration where they have the opportunity to interact with each other exchanging ideas, exploring alternatives, and learning from each other. In collaborative environment, learning is not a spectator sport but a participatory one where knowledge and ideas are created by active learners who have the opportunity to totally and actively be involved in their own learning (Meier, 2000, Meyers and Jones, 1993; Markova, 1992). Collaborative learning is an educational approach to teaching and learning that involves groups of students working together to solve an identified problem, complete a given task, and/or create a new desirable product. It is based on the idea that learning is a naturally social act in which the participants talk among themselves and thus, it is through the talking, listening, writing, and reflecting that active learning occurs (Meyers and Jones, 1993; Gerlach, 1994):

Collaborative learning processes can be incorporated into a typical 50-minute class in a variety of ways. Some require a thorough preparation, such as a long-term project, while others require less preparation, such as posing a question during lecture and asking students to discuss their ideas with 
their neighbors (see concept tests). As Smith and MacGregor state, "In collaborative classrooms, the lecturing/listening/note-taking process may not disappear entirely, but it lives alongside other processes that are based in students' discussion and active work with the course material." Regardless of the specific approach taken or how much of the ubiquitous lecture-based course is replaced, the goal is the same: to shift learning from a teacher-centered to a student-centered model. (NISE, 1997, ๆ. 8)

As reported by Center for Teaching Innovation (CTI) at Cornell University, collaborative learning and activities which are based on the view that knowledge is a social construct are most often based on the following four principles:

(1) The learner or student is the primary focus of instruction; (2) Interaction and "doing" are of primary importance; (3) Working in groups is an important mode of learning; and (4) Structured approaches to developing solutions to real-world problems should be incorporated into learning. (CTI: https://www.cte.cornell.edu/teaching-ideas/engaging-students/collaborative-learning.html).

Furthermore, collaborative learning provides many benefits. The following are only five benefits that are also cited by the Center For Teaching Innovation at Cornell University:

(1) Development of higher-level thinking, oral communication, self-management, and leadership skills; (2) Promotion of student-faculty interaction; (3) Increase in student retention, self-esteem, and responsibility; (4) Exposure to and an increase in understanding of diverse perspectives; and (5) Preparation for real life social and employment situations.

(CTI: https://www.cte.cornell.edu/teaching-ideas/engaging-students/collaborative-learning.html).

In short, collaborative learning provides the opportunity and the platform for students to be active, social, engaging, self-empowered, and motivated. Each is an essential ingredient for the educational experience that leads to deep learning, civic engagement, and social responsibility. It is also a good method for maximizing student learning retention because it is a good platform for active discussion, practice doing and teaching others. However, it is important that both educators and students differentiate between collaborative learning and cooperative learning.

Collaborative learning is similar to, but not the same as, cooperative learning. In cooperative learning the task is divided vertically (i.e., members work more or less concurrently on different aspects of a project), whereas in collaborative learning the task is divided horizontally (i.e., members work together more or less sequentially on different aspects of a project) (Dillenbourg, 1999). Collaborative learning is based on the view that knowledge is a social construct. Collaborative activities are most often based on four principles that "The learner or student is the primary focus of instruction; Interaction and "doing" are of primary importance; and Working in groups is an important mode of learning. (Chandra, 2015, p. 4).

However, to ensure an authentic collaboration and desirable success in collaborative learning tasks, faculty and instructors need to know their students and what each group of them can or cannot do. Knowing that enables teachers and instructors to better facilitate the collaboration process and provide the right needed guidance and advice to both individual students as well as to a team of students as a whole.

\subsection{Tutoring Inside and Outside the Class}

When colleges and universities admit students into their programs that means they committed themselves to help students succeed by creating the right learning environment for students to learn. This means that colleges and universities have the obligations to do everything in their power to help them succeed. One of the many ways of doing is to create tutoring centers for their students, especially those who are in their first year. Colleges and universities not only need to create "Tutoring Centers" but also be made aware that many students might assign negative connotations to visit tutoring centers. As Cherif, Movahedzadeh, Adams, and Martyn (2015) recommended, two things need to be done to overcome this challenge: First, rename "Tutoring Centers" to "University and Community Service Centers." Second, make going to "University and Community Service Centers" mandatory for first-year college students. They may go there to either receive or provide academic help to other students. When all first-year students must go to these centers, the activity loses its negative connotations, and everyone wins. Students go to the College and Community Service Center to serve or be 
served; to tutor or be tutored; to help or to get academic help (Cherif, Movahedzadeh, Adams, Martyn 2013; $2014 ; 2015)$.

Another critical related phenomenon to student's academic readiness is that, so often a number of students register and take college courses only to discover that they don't have the background, concepts, and skills to succeed in these courses. As a result, most of them struggle throughout the courses and many students drop or fail them. In situations such as this, students should have the opportunity to go to the learning center to get the right help and support. However, these type of students should also have the opportunity to drop the course and take lower-level courses of the same subject for non-credit to ensure they have the needed background to succeed in completing a given course. There is clear evidence that non-credit courses for Student's Readiness have been very effective in helping students to become academically ready for a given course and college work and in turn to succeed in their chosen academic programs.

\subsection{Health and Wellness Center}

Colleges and universities have discovered that making students healthy can result in unexpected benefits not only for students' health and lifestyles but also for faculty, administrators, and the institution. The concept of helping students succeed at the college level has in the last years being extended to include also the health and wellness of the students. In the last ten years, colleges and universities in the United States and Western Europe have experienced tremendous growth in the mission, services, and facilities of health centers to go beyond just clinic to treat the sick and injured. Today, driven by a broader and better understanding of health and its impact on learning, many institutions of higher education in western societies provide much more (Skorton and Altschuler, 2013; Schmalz, 2018; Blumenstyk, 2018; Jackson, 2019). There are many reasons behind today's urgent and increasing demand for health centers in learning institutions than ever. For example,

More students today come to campus with significant health needs, including mental health challenges. One in four is already taking psychotropic drugs - which enable some to go to college who would not otherwise function well enough. And many need help managing serious conditions like asthma, ADHD, eating disorders, addiction, autism-spectrum disorders, and physical disabilities. (Skorton and Altschuler, 2013a, ๆ. 4).

There is no doubt that motivating students who are under significant health needs is more challenging to be achieved by the class professors alone. Because of this, colleges and universities have become aware of the value of preventative medicine and healthy lifestyles among the student population. As a result, worldwide, "the mission of health centers is being redefined to include not just treating medical problems but also managing serious chronic conditions and promoting healthy habits" more (Skorton and Altschuler, 2013a). In short, it is easier to motivate and inspire healthy students to invest more of their time and energy on learning than those with concerning mental, physiological, and or biological health issues. The good news is that making students healthy takes many forms that can be put all under one roof including recreational facilities, health and counseling services, and clinic services.

One recent example of how colleges and universities in the United States are dealing with the issue of hunger among the students comes from the City Colleges of Chicago. To help take stress off students' plates and help them focus on more learning, Harold Washington College of Chicago has recently opened food pantry on the campus in collaboration with the Greater Chicago Food Depository. The college wants the students who are in need for food to come and take advantage of an on-site food pantry that is open for all the students in need. For now, any student enrolled in the college can come to the on-site food pantry within the college and take whatever they need once a month. The goal of the City Colleges of Chicago is to have food pantries at all the seven campuses in the city of Chicago by 2020. Many students reported that "the food pantries were a tremendous help because between work, class, and study, they didn't have time to get food or the money to buy groceries" (Hart, $2018, \uparrow ., 4)$.

\subsection{Students Teaching Students in Small-group Setting}

It has been well documented that students retain more than $90 \%$ of what they study and learn when they teach it to others (Figure 8). In addition, there is a lot of evidence that students learn best from their own peers. If so, then faculty need to provide the opportunity for the students not only to interact with each other but also to teach each other and play an active role in both the teaching and the learning process. By intentional design, peer 
teaching involves students teaching students in a small group settings, where the teaching role passes from student to student until each student has taught at least once. The teaching is done under the supervision of the classroom instructor who divides the class into small groups, giving each group a topic that is closely related to the other groups' topics and all parts of what the students are supposed to learn in a given academic course.

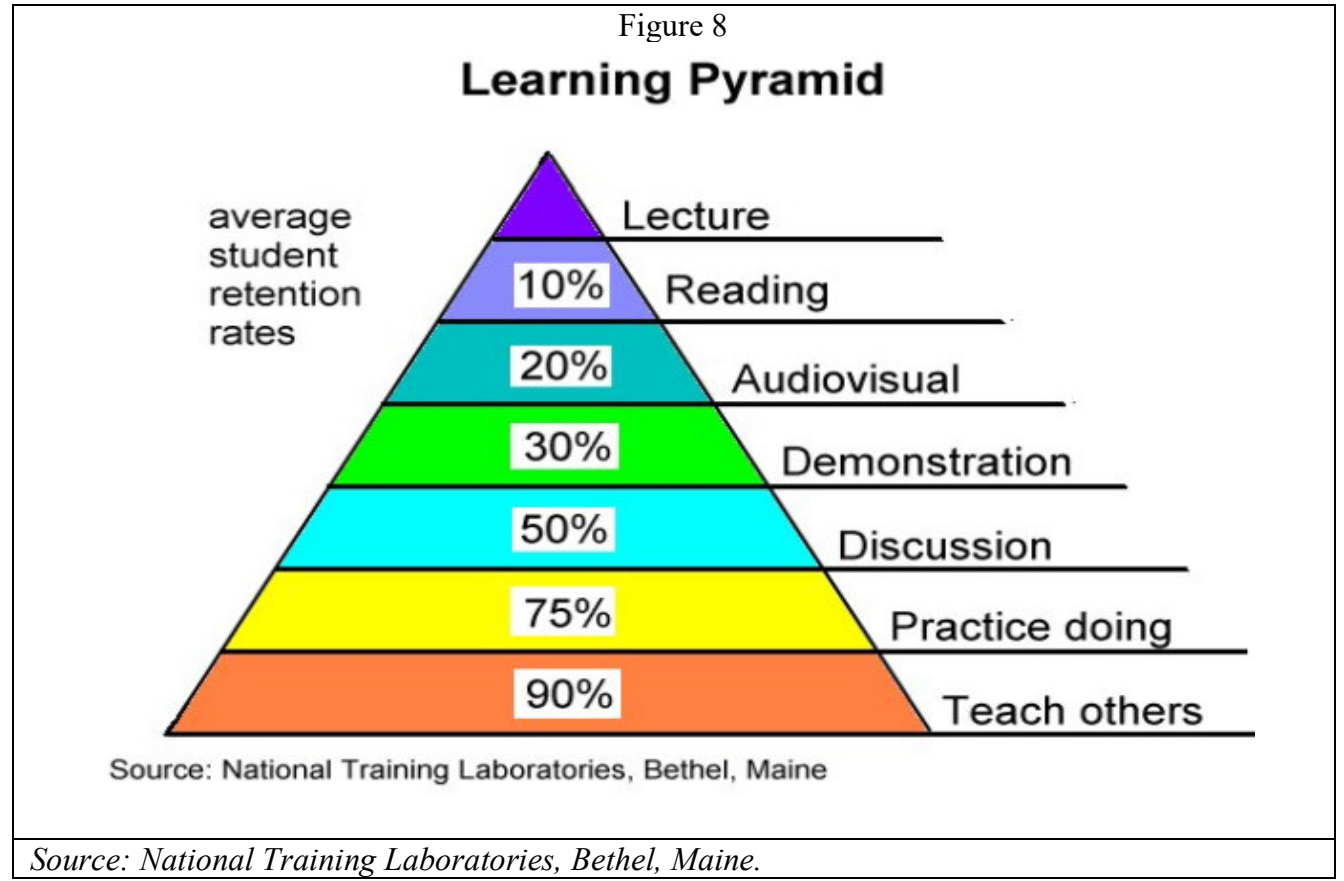

Peer teaching in small group settings is an excellent learning method because it is student-centered, selfdirected, and involves cooperative group research investigation. It aims to help students achieve breadth of knowledge and a depth of understanding beyond the core concepts and skills of the studied topics, by teaching them self-learning responsibilities. These self-learning responsibilities, which are a natural part of peer teaching, include conducting individual research, understanding the findings, and communicating their understanding to other students. By participating in this learning method, students will have the opportunity to acquire abilities and skills such as collecting information, organizing data, thinking critically, making a decision, detecting problems and generating a solution, communicating effectively, and writing clearly. Students will also learn about the relationship between the studied concepts and understanding the impact that those concepts will have on their lives (Cherif 1993; 2012; Tuttle, 2018). The role of the classroom instructor in the peer teaching approach is to facilitate group activity by (1) identifying and establishing the concepts, theories, and/or topics that needed to be learned; (2) monitoring the small group's processes, and (3) evaluating the final product in a meaningful way.

\subsection{Higher Academic Grade Value for Pre-class Assignment}

Many faculty and instructors complain that their students come to classes unprepared without having done the reading assignment required for a given lecture or class meeting. One of many effective approaches that advocated in literature to be effective in dealing with this matter and in motivating students to come to class highly prepared and ready to engage is, for example, just by giving an equal or greater weight to the "Be Ready for Class" assignments as to the "After Class" homework assignments. A number of studies show that students respond positively and spend extra time and effort when they know that they are also going to get a grade for readying the class materials before coming to every class meeting. The challenge faculty and instructors are to make sure that they have the mechanism to identify who did the reading, completed the assignments, etc. before coming the class (Cherif, Movahedzadeh, Adams, Martyn, 2014).

\subsection{Use of Analogies in the Classrooms}

Studies have shown that analogical thinking and the use of analogy motivates learners, accelerates learning, and 
deepens their comprehension. Analogies are a powerful teaching tool that aids in teaching difficult material by connecting the unknown with known and unfamiliar with the familiar. They are an effective platform for students to demonstrate their level of understanding of a learning concept. Asking students to come up with analogies to what they have learned to demonstrate their level of understanding have been found to be very useful for both challenging students to think, and to provide a platform for students to demonstrate their understanding (Cherif, Gialamas, Suida, Roze, and Movahedzadeh, 2015). After all, as Root-Bernstein (1999) clearly stated, "It is not our senses that limit or liberate us, but our ability to illuminate the unknown by means of analogies to the known. Learning itself depends on analogizing." An analogy is defined in the Webster's Dictionary (1983), as "a similarity or likeness between things in some circumstances or effects, when the things are otherwise entirely different... In biology, [analogy is] similarity in function between parts dissimilar in origin and structure ... In logic, [analogy is] the inference that certain admitted resemblances imply probable further similarity." (p., 64). In short:

Just as an enzyme regulates and speeds up the chemical process, an analogy facilitates and shapes understanding and speeds up the process of comprehension. Like an enzyme that helps complete a chemical reaction that is prerequisite to other reactions, an analogy helps develop understanding that is needed for further understanding to be developed. For these and other key reasons, instructors every day in almost every classroom have been using analogies to get their points across to students and to increase their chances of success. (p., 64).

\subsection{Lecture Attendance in Our Digital World of Web-based Education}

Literature has shown that students class and lab attendance correlates positively with better student's performance, with turning in assignments on time, and with stronger student active engagement in the learning process. On the other hand, many college faculties have argued that many of their students don't attend class regularly or actively participate in class discussions. However, in our digital world of Web-based education, the concept of "attendance" needs to be redefined in a way that still makes students responsible for attendance goals and objectives but also provides them with the flexibility to "attend" either digitally or physically, or both.

\subsection{Use of YouTube in the STEM Courses}

YouTube is a video-sharing website and depending on the type of users (registered or unregistered use), it allows users to upload, share, and view videos. Today, YouTube is not only one of the most used social media sites in the world, but it is also a very useful educational tool, especially when integrated into the design of the course and teaching materials. Instructors should learn how to integrate YouTube videos into their courses, and also spend extra energy and time searching for the right videos that will complement and enhance their teaching and enrich the learning experience for their students. Analyzing related literature indicates that the majority of college students have been using, on their own, YouTube videos to help them, for example, in their Biology and/or Chemistry courses, and most of them found the videos to be helpful in a variety of ways (Cherif, Siuda, Movahedzadeh, Cannon, and Ayesh, 2014). This might not be surprising since YouTube is one of the most used social media sites. But what is significant, is finding that YouTube videos are useful educational tools for many students and could be even more so if intentionally integrated into the design of the course and teaching materials.

Integrating the use of YouTube videos in planning curriculum, in teaching and selecting the learning material, and in assessing student learning and understanding can help faculty in their efforts to increase the rate of student satisfaction, performance, and retention. These are the reliable and desirable elements of measurement in student success. Therefore, for faculty who teach modern learners, the use of YouTube videos can be an indispensable part of effective curriculum development, teaching strategies, and learning materials and resources (Cherif, Siuda, Movahedzadeh, Cannon, and Ayesh, 2014). For example, the Khan Academy videos alone have been watched by more than 20 million people across the world (Barseghian, 2012).

\subsection{Pedagogical Course Concept Map}

Literature has indicated that students who have Pedagogical Course Concept Map on hand before starting a given course have a better chance of successfully completing and passing a given course. The Pedagogical Course Concept Map show students how the Conceptual (concepts, theories, numbers, and facts, application, etc.), Procedures (methods, hands-on, minds-on, etc.), and Laboratories (Investigation, application, etc.) are 
connected and related in a given course. It helps students not only to see how they can make the connection between the learned knowledge and their potential application, but also how students themselves might contribute to the growing field by constructing new related knowledge and information (McManamon, Nottingham, Murphy, Cherif, and Aron, 2013). After all, learning is all about making connections - "whether the connections are established by firing synapses in the brain, the "ah ha" experience of seeing the connection between two formerly isolated concepts, or the satisfaction of seeing the connection between an abstraction and a "hands-on" concrete application" (Cors 1999).

\subsection{Weekly Class Time Allocation}

Most of us still remember the challenging experiences that we faced when we went to the colleges or universities for the first time. Today's students are no different, they face the same challenges simply because unlike high school life and courses college life, courses require a significant time investment and commitment outside of labs and classrooms. Many studies have associated the declining academic performance among college students to poor time management and heavy partying among many students. Regardless of the various root causes that lead to poor time management, without some kind of well-designed intentional intervention from the college administrators, the instructors of the classes, and/or the parents, a given student is unlikely to succeed. The consequence is predictable and always the same, higher rate of student's drooping classes or withdrawing for a semester which in turn leads to lower student's success rate in a given class, and college level (Lucier, 2011; Ondracek, 2012; Cherif, Movahedzadeh, Adams, and Dunning 2013; Heibutzki, 2019). Given the fact that over $30 \%$ of students drop out after their first year of college, and almost half might never even graduate, helping students to establish sound time-management skills will increase the likelihood of most of them completing college experience and graduate with college degree.

Therefore, there is no doubt that students who are educated in advance about the time commitment and time required to actively participate in a given course performed better than those who don't have this information beforehand. Many students become overwhelmed with course materials and assignments and at the end being behind for class work. As a result, they drop or fail classes simply because they lack self-discipline and better time management. From the first class meeting, students are provided with a detailed "Weekly Class Time Allocation" and the time required to actively participating in this class. These times are considered average; it may take some students less time while it may take others more time. Table 2 below is an example of what "Weekly Class Time Allocation" looks like for a given week in a given course. It's purpose is to give the students an idea of the time needed to allocate each week in order to successfully complete this course. Times vary for an individual student, typical expected variation about 4 hours. (McManamon, Nottingham, Murphy, Cherif, and Aron, 2013; Cherif, Movahedzadeh, Adams, 2013)

\section{Final Remark}

There is a correlation between lack of self-motivation and lack of perseverance. Students with strong selfmotivation apply their perseverance, mental capability, and energy to do everything in their power to gain the required knowledge and skills needed to succeed in new courses and programs no matter how hard the task is. It is not only the student's responsibility, but it is also the responsibility of instructors and college administrations to keep students motivated after admitting them to their colleges, programs, and courses. We have to keep in mind that the faculty, educators, and college administrators are those who control the learning materials, learning environment, and pedagogy through which they can influence student's motivation, study habits, and attitudes, and help them see the relevance of what they learn to their lives and future careers. As S. I. Hayakawa, psychologist, semanticist, teacher, writer, US Senator, once cited saying, "The best teachers may never 'teach" anything at all. In contrast, they create vast environments in which vast amounts of learning may take place". M. Q. Patton, (1997) clearly stated that we don't really learn from experiences, but we learn from the reflection on our own experience. If we want the modern students and the coming generations of students to learn and be successful in learning, we need"... the dedicated teaching of students requires a constant and often systematic search for answers to puzzles such as how best to implant an idea into a human mind", as Professor John Janovy Jr. (1985), stated many years ago. 


\begin{tabular}{|c|c|c|c|c|}
\hline \multicolumn{5}{|l|}{ Table 2} \\
\hline \multirow[b]{2}{*}{$\begin{array}{l}\text { Students who are } \\
\text { educated in advance } \\
\text { about the time } \\
\text { commitment and time } \\
\text { required to actively } \\
\text { participate in a given } \\
\text { course performed better } \\
\text { than those who don't } \\
\text { have this information } \\
\text { beforehand. }\end{array}$} & & Assignment & $\begin{array}{l}\text { Time to } \\
\text { Allocate }\end{array}$ & Total Time \\
\hline & $\begin{array}{c}\text { Week } \\
3\end{array}$ & $\begin{array}{l}\text { - Reading and Preparation } \\
\text { - Discussion \#1 } \\
\text { - Discussion \#2 } \\
\text { - Interactive Learning Activity } \\
\text { Week 3: ILA \#7 and } 8 \\
\text { - Homework } \\
\text { Review } \\
\text { Quiz }\end{array}$ & $\begin{array}{l}2.0 \text { hours } \\
.5 \text { hours } \\
.5 \text { hours } \\
.5 \text { hours } \\
3.0 \text { hours } \\
2.0 \text { hours } \\
2.0 \text { hours } \\
2.0 \text { hours }\end{array}$ & 12.5 hours \\
\hline \multicolumn{5}{|c|}{$\begin{array}{l}\text { Weekly Time Allocations } \\
\text { It is very important that students understand the time required to actively participate in this class. } \\
\text { These times are considered average; it may take some students less time while it may take others } \\
\text { more time. The purpose of this chart is to give the students an idea of the time needed to allocate } \\
\text { each week in order to successfully complete this course. } \\
{ }^{\star} \text { Times will vary for individual students typical expected variation }=+/-4 \text { hours }\end{array}$} \\
\hline \multicolumn{4}{|c|}{ (McManamon, et.al, 2013; Cherif, el.at. 2014, Movahedzadeh, et.al, 2017) } & 3 \\
\hline
\end{tabular}

\section{References}

Ames, C., (1990). Motivation: What teachers need to know? Teachers College Record, 1990. 91(3): p. 409-421. Barrow, Robin, and Milburn, Geoffrey (1990). A Critical Dictionary of Educational Concepts (2nd). New York: Teacher College Press.

Barseghian, T. (2012). How teachers make cell phones work in the classroom. Retrieved July, 2012. 5: p. 2012. Berchiolli, Barbara, Movahedzadeh, F., and Cherif, A. (2018). Assessing Student Success in a Project-Based Learning Biology Course at a Community College. The American Biology Teacher 80(1):6-10. DOI: 10.1525/abt.2018.80.1.6

Blumenstyk, Goldie (2018). While Congress Squabbles, Some States Take Their Own Steps to Help Hungry Students. Chronicle of Higher Education, May 24, 2018. https:/www.chronicle.com/article/WhileCongress-Squabbles-Some/243505

Bomia, L., et al., (1997). The Impact of Teaching Strategies on Intrinsic Motivation.

Bushweller, Kevin (2019). The Kids Are Right: School Is Boring. Education Week, January 8, 2019. https://www.edweek.org/ew/articles/2019/01/09/the-kids-are-right-school-is-boring.html?cmp=eml-enleu-news1-rm\&M=58716912\&U=2170116\&UUID=a8f2901 ef753ef67457054431aef7c31

Chandra, Ritu (2015). Collaborative Learning for Educational Achievement. IOSR Journal of Research \& Method in Education(IOSR-JRME). e-ISSN: 2320-7388, p-ISSN: 2320-737X Volume 5, Issue 3 Ver. I (May-Jun.2015), PP 04-07

Cherif, Abour (2010). How well do you know your students? The American Biology Teacher, volume 73, No. 1, pp. 6-7.

Cherif, Abour (2012). Promoting Understanding Through Peer Teaching In Small Group Settings. Washington Science Teacher Journal, Vol. 53 (1): 24-31. https://www.researchgate.net/publication/318469113_Promoting_Understanding_Through_Peer_Teach ing_In_Small_Group_Settings

Cherif, Abour (1993). Peer Teaching In Small Group Setting. Forward to Excellence in Teaching and Learning, Vol. 1, No. 2: 5-7 http://www.abourcherif.com/pdfs/Peer\%20Teaching\%20in\%20Small\%20Group\%20Settings.pdf

Cherif, A., Movahedzadeh, F., Adams, G., and Dunning, J. (2013). Why Do Students' Fail: Student's Perspectives. In A Collection of Papers on Self-Study and Institutional Improvement 2013. Higher Learning Commission, Chicago (35-51).

Cherif, A., Gialamas, S., Siuda, J., Roze, M., \& Movahedzadeh, F. (2015). Enhancing Student Understanding Through Analogies in Teaching Science Concepts: Teacher and Faculty Perspectives. Pinnacle Educational Research \& Development, ISSN: 2360-9494, Vol. 3 (3), 2015, Article ID perd_185, 579588, 2015. https://pjpub.org/perd/perd_185.pdf 
Cherif, A., Adams, G., Movahedzadeh, F., Martyn, M., McManamon, J (2015). Do College Students Give a Flip About Flipped Learning? Journal of Higher Education Management, 3(1): 191-

215.http://www.aaua.org/journals/pdfs/JHEM\%2030\%20ONLINE.pdf

Cherif, A., Siuda, A., Movahedzadeh, F., Cannon, C., and Ayesh, S. (2014). College Students' Use of YouTube Videos In Learning Biology and Chemistry Concepts. Pinnacle Educational Research \& Development, Vol. 2 (6):2-15.https://pjpub.org/Abstract/abstract_perd_149.htm

Cherif, A., Roze, M., and Gialamas, S. (2016). The Free Classroom Creative Assignment: Leveraging Student Strengths to Enhance Learning. International Schools Journal, Vol.35, No. 2 (April 2016): https://www.questia.com/library/journal/1P3-4123081011/the-free-classroom-creativeassignment-leveraging

Cross, K. P. \& M. H. Steadman (1996). Classroom research: Implementing The Scholarship of Teaching. Jossey-Bass.

Dillenbourg, P. (1999). Collaborative Learning: Cognitive and Computational Approaches. Advances in Learning and Instruction Series. New York, NY: Elsevier Science, Inc.

Fowler, Susan (2014). Why Motivating People Doesn't Work and What Does? San Francisco: Berrett-Koehler Publishers, Inc.

Garrison, R, and Vaughan, N. (2008). Blended Learning In Higher Education: Framework, Principle, and Guidelines. San Francisco, CA: Jossery-Bass, A Wiley Imprint.

Gerlach, J.M. (1994). Is this collaboration? New directions for teaching and learning, 1994. 1994(59): p. 5-14.

Hart, Rob (2018). Permanent Food Pantry Opens At Harold Washington College. WBBM News Radio, https://wbbm780.radio.com/city-colleges-chicago-food-pantry-harold-washington

Heibutzki, Ralph (2019). College Students. Education SeattlePi: https://education.seattlepi.com/lack-timemanagement-affects-college-students-1093.html

Honeycutt, B. \& Garrett, J. (September 2013). The flipped approach to a learner-centered class. (Whitepaper). Magna Publications.

Honeycutt, B. \& Glova, S. (2014). Can You Flip an Online Class? Faculty Focus. Online Education. March 31, 2014. http://www.facultyfocus.com/articles/online-education/can-flip-online-class/

Howe, Neil (2014). The Silent Generation, "The Lucky Few" (Part 3 of 7). Forbes, 13, 2014, 10:52am. https:/www.forbes.com/sites/neilhowe/2014/08/13/the-silent-generation-the-lucky-few-part-3-of7/\#219233212c63

Jackson, Lily (2019). The U.S. Did a Major Report on Campus Hunger. Here Are 3 Takeaways. Chronicle Of Higher Education, JANUARY 09, 2019. https:/www.chronicle.com/article/The-US-Did-a-MajorReport-

on/245442?cid=at\&utm_source=at\&utm_medium=en\&elqTrackId=cde5368f766b483894f $29 \mathrm{fc} 7295 \mathrm{~cd} 1$ fc\&elq=f525c487272540 cea $16210 \mathrm{e} 87 \mathrm{~d} 6 \overline{\mathrm{e}} 44 \mathrm{c} 3$ \&elqaid=21927\&elqat=1\&elqCampaignId=10705

Jackson, Robyn R. (2011). How to Motivate Reluctant Learners (Mastering the Principles of Great Teaching series). Alexandria, VA: ASCD Books. http://www.ascd.org/Publications/Books/Overview/How-toMotivate-Reluctant-Learners.aspx. http://thuvienso.bvu.edu.vn/bitstream/TVDHBRVT/15176/2/Howto-Motivate-Reluctant-Learners.pdf

Janovy, John Jr. (1985). On Becoming a Biologist. New York: Harper \& Row, Publishers.

Kalkhurst, Dillon, (2018). Engaging Gen Z students and learners. PearsonEd.com, March 12, 2018. https://www.pearsoned.com/engaging-gen-z-students/

Kamauru, R., Intrinsic and Extrinsic Motivation Predict Academic Performance of College Students. Morehouse College, 2000.

Kane, Sally (2018). The Common Characteristics of Generation X Professionals. The Balance Career, Updated November 02, 2018, https:/www.thebalancecareers.com/common-characteristics-of-generation-Xprofessionals-2164682

Kleinschmit, Matt (2018). Generation Z characteristics: 5 infographics on the Gen Z lifestyle. Vision Critical, https://www.visioncritical.com/generation-Z-infographics/https://www.visioncritical.com/generation-zinfographics/

Lang, James (2019). How to Teach a Good First Day of Class. Chronicle of Higher Education, January 4, 2019. https://www.chronicle.com/interactives/advice-

firstday?cid=wb\&utm_source=wb\&utm_medium=en\&elqTrackId=a4e2c9c8a84049d6ae6cbea52cd4cb 1d\&elq=cb76ad1b58ca4308aea5806c38176d95\&elqaid=21944\&elqat=1\&elqCampaignId=10720.

Lucier, Kelci Lynn (2011). Learn to Manage Your Time in College. US NEWS: Oct. 5, 2011, at 8:30 a.m. https://www.usnews.com/education/blogs/the-college-experience/2011/10/05/learn-to-manage-yourtime-in-college

Lumsden, L.S., (1994). Student Motivation To Learn. ERIC Digest, Number 92. 
MacGregor, J. (1990). "Collaborative learning: Shared inquiry as a process of reform" In Svinicki, M. D. (Ed.), The changing face of college teaching, New Directions for Teaching and Learning No. 42.

Markova, Dawna (1992). How Your Child Is Smart. Berkreley, CA: Conari Press.

Marshall, H.H., (1987). Motivational strategies of three fifth-grade teachers. The Elementary School Journal, 1987. 88(2): p. 135-150.

McManamon, J., Nottingham, D., Murphy, M., Cherif, A., and Aron, B. (2013). Integrated Mathematics Course Design, Learning Strategies and Assessment Model. Presentation presented at the 2013 CITE Annual Conference, Center for Innovative Technology in Education at the JW Marriott Chicago, Chicago Illinois. April 2 - 4, 2013.

Meier, Davie (2000). The Accelerated Learning Handbook. New York: McGraw-Hall

Metzger, K., (2013). Starting Right: Using “Biophilia," Organism Cards, \& Key Themes in Biology to Introduce Student-Centered Active-Learning Strategies at the Beginning of a Course. The American biology Teacher, 2013. 75(4): p. 285-289.

Meyers, C. and Jones, T. (1993). Promoting Active Learning: Strategies For The College Classroom. San Francisco, CA: Jossery-Bass, A Wiley Imprint.

Movahedzadeh, F. (2011). Improving Students' Attitude toward Science through the Blended, Science Education and Civil Engagement, An International Journal, 3:2. http://article.sapub.org/pdf/10.5923.j.edu.20120207.17.pdf

Movahedzadeh, Farahnaz (2012). Improving Student Success Through Hybrid Mode of Delivery in Non Science Major Biology Classes. Education, 2012, 2(7): 333-339 DOI: 10.5923/j.edu.20120207.17. http://article.sapub.org/pdf/10.5923.j.edu.20120207.17.pdf

Movahedzadeh, F, and Cherif, A. (2015). Why Do Students Fail? Inspiring and Motivating Students in Taking a Charge of Their Own Education? Research presentation presented at the 2015 SENCER Summer Institute, Worcester Polytechnic Institute, Worcester, MA July 30-August 3, 2015.

NISE (1997). What is collaborative learning? National Institute For Science Education (NISE) - College Level One, 11/1/1997. http://archive.wceruw.org/cl1/CL/moreinfo/MI2A.htm

Novak, Jill (2018). The Six Living Generations In America. Marketing Teacher.Com. http://www.marketingteacher.com/the-six-living-generations-in-america/

Ondracek, Alex (2012). Bad sleeping habits affect grades, ability to absorb information in class. Kansas State Collegian. Sep 6, 2012: https://www.kstatecollegian.com/2012/09/06/bad-sleeping-habits-affect-gradesability-to-absorb-information-in-class/

Palmero, F. (2008). MOTIVACION Y EMOCION. ESPANA: S.A. MCGRAW-HILL / INTERAMERICANA DE ESPAN. A. https://www.casadellibro.com/libro-motivacion-y-emocion/9788448161019/1182841

Pappas, Christopher (2016). 8 Important Characteristics Of Baby Boomers eLearning Professionals Should Know. eLearning, January 29, 2016. https://elearningindustry.com/8-important-characteristics-babyboomers-elearning-professionals-know .

Price, Christy (2013). Motivating Students: From Apathetic to Inspired. Faculty Focus: Online Seminar, Thursday, March 28, 2013 Eastern. 1:00 pm (C) 2013 Magna Publications. http://www.facultyfocus.com/articles/teaching-and-learning/engaging-students-in-a-habit-of-gratitude/

Root-Bernstein, R. (1984). Creative process as a unifying theme in human culture. Daedalus, 113(3), 197-219. 28.

Root-Bernstein, R. and M. Root-Bernstein (1999). Sparks of Genius: The Thirteen Thinking Tools of the World's Most Creative People. Boston: Houghton Mifflin Company.

Ryan, R.M. \& Deci, E.L. (2000). Intrinsic and Extrinsic Motivations: Classic Definitions and new directions. Contemporary Educational Psychology, 25, 54-67.

Sackstein, Starr (2019). Always Remember to Ignite Imagination When Creating Learning Experiences. Education Week, January 3, 2019 4:32 AM.

Schmalz, Julia (2018). Hungry to Learn: Five Students Describe Their Struggles With Food and Housing. Chronicle Of Higher Education. https://www.chronicle.com/interactives/insecurity?cid=at\&utm_source=at\&utm_medium=en\&elqTrack $\mathrm{Id}=95$ eee0d3f940418990b84b725decb3b7\&elq=f525c487272540cea16210e87d $\overline{6}$ e 44c3\&elqaid=21927 \&elqat=1\&elqCampaignId=10705

Schuetz, Robert (2018). Project-Based Learning: Benefits, Examples, and Resources. Schoology.ComBlog, June 01, 2018. https://www.schoology.com/blog/project-based-learning-pbl-benefits-examples-and-resources

Senge, Peter (1992). Foreword. In Markova, Dawna (1992). How Your Child Is Smart. Berkeley, CA: Conari Press.

Skorton, D. and G. Altschuler (2013a). How college health centers help students succeed. Forbes, 2013.

Skorton, D. and G. Altschuler (2013b). MOOCs: A college education online? Forbes. 2013. 
Smith, B.L. and J.T. MacGregor (1992). What Is Collaborative Learning? In Goodsell, A. S., Maher, M. R., and Tinto, V. (Eds.), Collaborative Learning: A Sourcebook for Higher Education. National Center on Postsecondary Teaching, Learning, \& Assessment, Syracuse University.

Spencer, Ruby (2016). 6 Key Blended Learning Benefits for Corporate Training. Pulse Learning, May 2016, https://www.pulselearning.com/blog/6-key-blended-learning-benefits-corporate-training/

Spencer, Ruby (2016). 6 Key Blended Learning Benefits for Corporate Training. Pulse Learning, May 2016, https://www.pulselearning.com/blog/6-key-blended-learning-benefits-corporate-training/.

Treacy, D. J., et al., (2011). Implementation of a project-based molecular biology laboratory emphasizing protein structure-function relationships in a large introductory biology laboratory course. CBE Life Sciences Education, vol. 10, no. 1, pp. 18-24, 2011.https://www.lifescied.org/doi/10.1187/cbe.10-07-0085

Tuttle, Nicole (2018). Suggestions for Using Small Groups in the Classroom. University of Chicago, Department of Chemistry and Teaching Consultant at the Chicago Center for Teaching. https://teaching.uchicago.edu/resources/teaching-guides/small-group-work/

Woll, Samantha (2002). Bad habits, schedules determine student diets. Michigan Daily: March 28, 2002. https://www.michigandaily.com/content/bad-habits-schedules-determine-student-diets

\section{Appendixes}

Appendix 1

Participants Identified Categories of Root-cause Factors for Why Students Fail College

(Cherif, Movahedzadeh, Adams, Martyn 2013; 2014; 2015)

\begin{tabular}{|c|c|c|c|}
\hline \multicolumn{4}{|c|}{ Participants Identified Categories of Root-cause Factors For Why Students Fail College } \\
\hline & $\begin{array}{c}\text { Student's } \\
\text { Perspectives }\end{array}$ & $\begin{array}{c}\text { Faculty } \\
\text { Perspectives }\end{array}$ & $\begin{array}{l}\text { Academic leader's } \\
\text { Perspectives }\end{array}$ \\
\hline 1 & Motivation (35\%) & Not Ready for College $(38 \%)$ & Not ready for college work $(46 \%)$ \\
\hline 2 & Study habits (17\%) & Lack of Effort (12\%) & Lack of effort (14\%) \\
\hline 3 & $\begin{array}{l}\text { Academic } \\
\text { Preparedness (14\%) }\end{array}$ & $\begin{array}{l}\text { Lack of Motivation or Interest } \\
(12 \%)\end{array}$ & Lack of motivation $(10 \%)$ \\
\hline 4 & External Factors $(11 \%)$ & $\begin{array}{l}\text { Faculty Instruction and Behavior } \\
(12 \%)\end{array}$ & Cost of education $(7 \%)$ \\
\hline 5 & Attitudes (11\%) & Life, Work, and Careers (9\%) & $\begin{array}{l}\text { Structure of existing } \\
\text { Educational system }(7 \%)\end{array}$ \\
\hline 6 & Instruction $(10 \%)$ & Economic Issues (3\%) & Instruction-related matters $(5 \%)$ \\
\hline 7 & Relevancy (4\%) & Personality Issues $(6 \%)$ & Life, Work, and Careers (4\%) \\
\hline 8 & & $\begin{array}{l}\text { Facilities, Materials, Delivery } \\
\text { Systems }(8 \%)\end{array}$ & Leadership-related matters (4\%) \\
\hline 9 & & & Economic related issues $(3 \%)$ \\
\hline
\end{tabular}


Appendix 2

Today's Students Have All Kinds of Tools to Learning

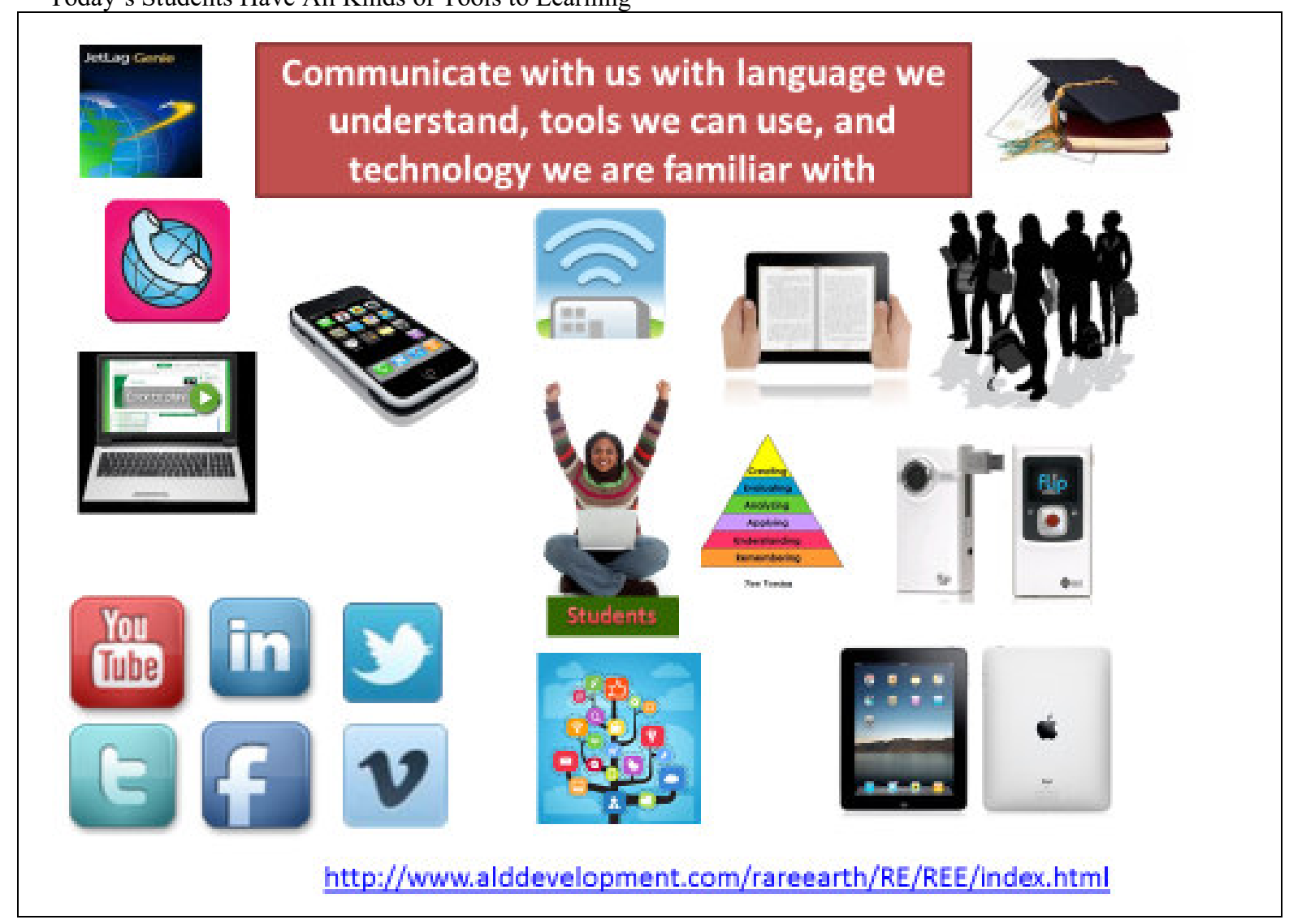

Appendix 3 Active Learning Requires Transforming Everything We Do In the Classroom

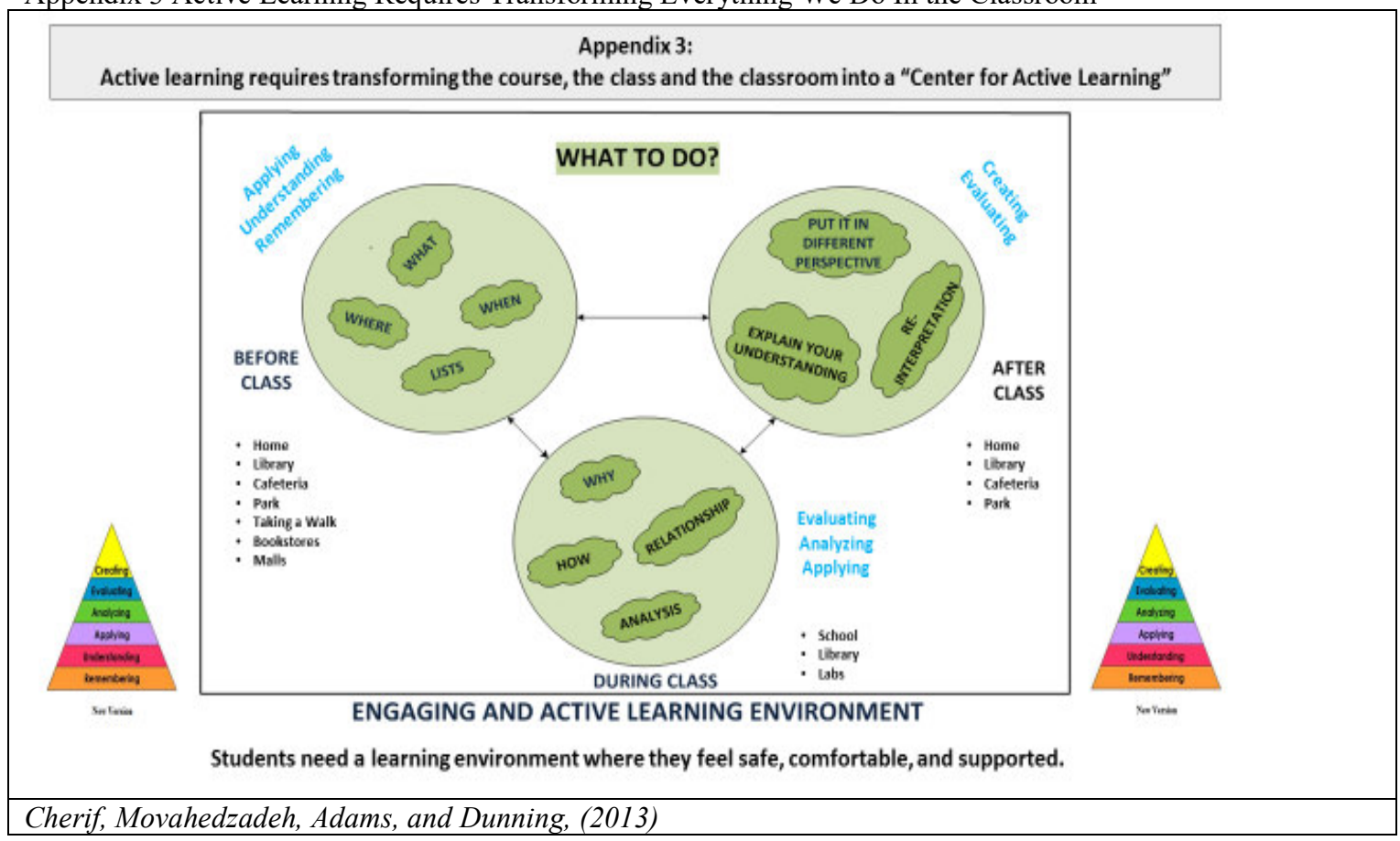

